\title{
Prediksi Curah Hujan Bulanan Di Kota Samarinda Menggunakan Persamaan Regresi Dengan Prediktor Data Suhu dan Kelembapan Udara
}

\author{
Satriogi Putramulyo ${ }^{a}$, Siti Alaa ${ }^{b^{*}}$ \\ ${ }^{a}$ Program Studi Fisika, Universitas Mataram, Jl. Majapahitno.62 Mataram 83125, Indonesia.mulyoseven@gmail.com \\ ${ }^{b *}$ Program Studi Fisika, Universitas Mataram, Jl. Majapahitno. 62 Mataram 83125, Indonesia. siti.alaa@unram.ac.id
}

\begin{abstract}
A B S T R A C T
Monthly rainfall predictions using predictors of air temperature and air humidity have been done in this research. Data was obtained from the Temindung Samarinda Meteorological Station. Evaluation is done by comparing and calculating the amount of deviation from monthly rainfall predictions to the rain of observations. The data used are daily data which are summed and leveled on a monthly basis from 2005 to 2015, while the 2016 data is used to compare the results of predictions to observations. Monthly rainfall predictions are carried out using multiple linear regression methods. The results of data processing showed that the prediction of 2016 monthly rainfall in Samarinda city experienced under estimate (smaller than its actual value) and the best prediction results occurred in October. Monthly rainfall predictions with predictors of air temperature and humidity produce a very strong correlation coefficient and good RMSE where $r=0.93$ and $\mathrm{RMSE}=46.26 \%$.
\end{abstract}

Keywords :rainfall prediction. regression, Samarinda.

\section{Pendahuluan}

Indonesia merupakan negara kepulauan yang dilintasi oleh garis khatulistiwa dimana cuaca dan iklim wilayah Indonesia dipengaruhi oleh dinamika atmosfer baik dalam skala global, skala regional dan skala lokal (Wirjohamidjojo dan Swarinoto, 2010). Salah satu daerah yang dilintasi oleh garis khatulistiwa adalah kota Samarinda. Secara geografis kota Samarinda terletak pada $0^{\circ} 21^{\prime} 81^{\prime \prime}-1^{\circ} 09^{\prime} 16^{\prime \prime} \mathrm{LU}$ dan $116^{0} 15^{\prime} 16^{\prime \prime}-117^{\circ} 24^{\prime} 16^{\prime \prime}$ BT sedangkan dilihat dari topografi kota ini memiliki ketinggian berkisar $10-200 \mathrm{~m}$ diatas permuakaan laut sehingga kota Samarinda memiliki iklim tropis basah yang mengakibatkan terjadinya hujan sepanjang tahun. Curah hujan di kota Samarinda diperkirakan 1980 mm/tahun (Sandy, 1995).

Di wilayah tropis, curah hujan merupakan salah satu unsur iklim yang paling tinggi keragamannya. Karakteristik curah hujan diberbagai daerah tentunya tidak sama. Kondisi ini diakibatkan oleh beberapa faktor, yakni: geografis, topografis, dan orografis. Belum lagi ditambah dengan struktur dan orientasi kepulauan (Swarinoto, 2011). Akibatnya pola sebaran curah hujan cenderung tidak merata antara daerah yang satu dengan daerah yang lain dalam ruang lingkup yang luas.

Kebutuhan terhadap ketersediaan data dan informasi yang aktual dan bahkan beberapa waktu ke depan telah mendorong berkembangnya berbagai model prediksi, baik yang berbasis statistik maupun yang berdasarkan pendekatan stokastik. Berbagai pendekatan model telah banyak digunakan untuk prediksi iklim baik dengan model statisitik maupun model deterministik. Adapun salah satu model prediksi menggunakan model statistik adalah dengan metode regresi (Handiana, dkk, 2013).

Berbagai kejadian anomali iklim yang sering kali berulang, akhirnya disadari bahwa pada dasarnya ada

\footnotetext{
* Corresponding author.

Alamat e-mail: siti.alaa@unram.ac.id
} 
ketergantungan antara dinamika atmosfer, dan indikator dominan yang sering digunakan untuk melihat gejala terjadinya anomali iklim adalah suhu dan kelembapan udara. Curah hujan merupakan parameter iklim yang terlihat jelas perilakunya akibat terjadinya anomali iklim (Prawirowardoyo, 1996). Hal ini pula yang dijadikan dasar dalam penyusunan model prediksi curah hujan yang dikembangkan dalam penelitian ini.

Mengingat bahwa hujan di wilayah tropis banyak berpengaruh terhadap kehidupan manusia dalam segala aspeknya (Wirjohamidjojo dan Swarinoto, 2010), maka penulis berusaha mengumpulkan dan melakukan pengolahan data curah hujan, suhu dan kelembapan udara dari tahun 2005 sampai 2015 di Stasiun Meteorologi Temindung Samarinda. Sementara itu untuk pembuatan prediksi total hujan bulanan digunakan metode regresi linier berganda. Prediksi total hujan bulanan dengan metode tertentu sangat sesuai dengan tempat yang satu, tetapi dapat juga tidak sesuai pada tempat yang lain. Untuk itu evaluasi prediksi total hujan bulanan sangat diperlukan sehingga hasil kajian dapat digunakan sebagai masukan dalam menyiapkan prediksi curah hujan bulanan pada bulan dan tahun berikutnya.

\section{Metode Penelitian}

Data yang digunakan dalam tulisan ini adalah data iklim yang diperoleh dari Stasiun Meteorologi Temindung Samarinda, yang terdiri atas data total curah hujan bulanan, data rerata suhu udara bulanan dan data rerata kelembapan udara bulanan. Data tersebut diperoleh dari situs $B M K G$ online (http://dataonline.bmkg.go.id/bmkg.online).

Data suhu udara dan kelembapan udara bulanan merupakan rata-rata bulanan hasil dari jumlah data rata-rata harian selama satu bulan kemudian dibagi dengan banyaknya data pada bulan yang bersangkutan. Panjang data yang digunakan adalah 11 tahun dari tahun 2005 sampai 2015. Data total hujan, suhu udara, dan kelembapan udara bulanan selama 11 tahun (2005-2015), digunakan untuk membentuk persamaan regresi. Data suhu udara dan kelembapan udara bulanan tahun 2016 digunakan untuk memprediksi dan membandingkan curah hujan.

Metode prediksi yang digunakan dalam penelitian ini adalah Regresi Linear Berganda. Metode prediksi regresi linier berganda ini dilakukan dengan cara membentuk persamaan regresi yang digunakan untuk melakukan prediksi curah hujan bulanan menggunakan lebih dari dari satu variabel independen. Hasil prediksi curah hujan bulanan menggunakan metode ini dibandingkan dengan hasil observasi BMKG sehingga dapat dijadikan prediksi curah hujan pada bulan dan tahun selanjutnya. Persamaan umum metode ini adalah sebagai berikut (Sudjana, 1995):

$\mathrm{Y}=\mathrm{A}+\mathrm{B} 1 \mathrm{X} 1+\mathrm{B} 2 \mathrm{X} 2+\ldots \ldots . \mathrm{BnXn}$

dimana : $\mathrm{Y}=$ Variabel dependen $; \mathrm{X}_{\mathrm{i}}=$ Variabel independen ; $\mathrm{B}_{\mathrm{i}}=$ Koefisien variable $; \mathrm{A}=$ Konstanta.
Metode Evaluasi yang digunakan dalam penelitian ini adalah root mean square error (RMSE) dan koefisien korelasi. RMSE digunakan untuk mengetahui besarnya penyimpangan yang terjadi antara nilai prediksi curah hujan dibandingkan dengan nilai curah hujan aktualnya (observasi) yang terjadi selama satu tahun (Wilks, 1995). Perlu diketahui bahwa untuk validasi hasil prakiraan semakin besar nilai RMSE, maka semakin jauh nilai data curah hujan bulanan prakiraan terhadap curah hujan aktualnya dan semakin kecil nilai RMSE maka semakin baik prediksi total hujannya. Karena tingkat kesalahan yang dapat diminimalisir dapat meningkatkan tingkat akurasi prakiraan (Soetamto dan Maria, 2010).

$$
\mathrm{RMSE}=\left[\frac{1}{N} \sum_{n=1}^{N}\left(f_{n}-r_{n}\right)^{2}\right]^{\frac{1}{2}}
$$

dimana : $f_{n}=$ Data curah hujan hasil obsevasi $; r_{n}=$ Data curah hujan hasil prediksi.

Nilai koefisien korelasi Pearson (Trihendradi, 1995) digunakan untuk menentukan besarnya hubungan atau kedekatan antara total hujan yang telah diprediksi dengan curah hujan aktual yang terjadi. Kuat tidaknya hubungan (Prihatini dan Swarinoto, 2010) antara prediksi curah hujan bulanan dengan curah hujan observasinya dapat diukur dengan suatu nilai yang disebut dengan koefisien korelasi. Nilai koefisien korelasi ini paling sedikit -1 dan paling besar 1. Untuk Validasi hasil prakiraan dengan menggunakan koefisien korelasi, semakin kuat korelasi maka semakin baik hasil validasi berarti semakin tinggi tingkat akurasi prakiraan.

$$
\mathrm{r}=\sqrt{1-\frac{\sum(Y-Y *)^{2}}{\sum(Y-\bar{Y})^{2}}}
$$

dimana : $r=$ nilai korelasi ; $\mathrm{Y}=$ data curah hujan bulanan observasi ; $\mathrm{Y}^{*}=$ data curah hujan bulanan hasil prediksi ; $\bar{Y}=$ rata-rata data curah hujan bulanan observasi.

\section{Hasil dan Diskusi}

Prediksi menggunakan data dari tahun 2005 sampai 2015 sebagai analisa sedangkan tahun 2016 digunakan untuk melihat hasil prediksi dengan curah hujan aktualnya. Bentuk persamaan regresi linier berganda hasil pengolahan menggunakan data suhu udara, kelembapan udara dan curah hujan bulanan dicantumkan pada Tabel 1. Perbandingan untuk hasil prediksi dengan data hasil observasi dapat dilihat pada Tabel 2. dan Gambar 1.

Hasil prediksi curah hujan bulanan di kota Samarinda dapat dikatakan hampir akurat, ini dikarenakan pola curah hujan prediksi mengikuti pola curah hujan hasil observasi. Semakin mengikuti pola maka prakiraan curah hujan semakin akurat. Dari Hasil perhitungan menunjukan bahwa di dapat nilai koefisien korelasi antara prediksi curah hujan bulanan dengan prediktor suhu dan kelembapan udara terhadap data observasi kota Samarinda didapat nilai koefisien korelasinya sebesar $r=0,93$ dan nilai RMSE-nya sebesar 46,26\%. 
Tabel 1. Persamaan linear berganda menggunakan prediktor suhu dan kelembapan

\begin{tabular}{ll}
\hline \multicolumn{1}{c}{ Bulan } & $\begin{array}{l}\text { Prediksi Regresi Linear } \\
\text { Berganda }\end{array}$ \\
\hline Januari & $\mathrm{Y}=416,37-30,01 \mathrm{X}_{1}+7,57 \mathrm{X}_{2}$ \\
\hline Februari & $\mathrm{Y}=332,09-22,76 \mathrm{X}_{1}+5,58 \mathrm{X}_{2}$ \\
\hline Maret & $\mathrm{Y}=6,87-2,06 \mathrm{X}_{1}+2,04 \mathrm{X}_{2}$ \\
\hline April & $\mathrm{Y}=-1599,6+1,07 \mathrm{X}_{1}+22,18 \mathrm{X}_{2}$ \\
\hline Mei & $\mathrm{Y}=576,94-10,90 \mathrm{X}_{1}+8,09 \mathrm{X}_{2}$ \\
\hline Juni & $\mathrm{Y}=-90,27-20,42 \mathrm{X}_{1}+9,8 \mathrm{X}_{2}$ \\
\hline Juli & $\mathrm{Y}=-193,78-26,68 \mathrm{X}_{1}+13,56 \mathrm{X}_{2}$ \\
\hline Agustus & $\mathrm{Y}=-501,02-1,28 \mathrm{X}_{1}+7,33 \mathrm{X}_{2}$ \\
\hline September & $\mathrm{Y}=516-39,13 \mathrm{X}_{1}+8,57 \mathrm{X}_{2}$ \\
\hline Oktober & $\mathrm{Y}=402,67-17,17 \mathrm{X}_{1}+3,10 \mathrm{X}_{2}$ \\
\hline November & $\mathrm{Y}=1347,6-73,18 \mathrm{X}_{1}+10,56 \mathrm{X}_{2}$ \\
\hline Desember & $\mathrm{Y}=1365-71,35 \mathrm{X}_{1}+9,99 \mathrm{X}_{2}$ \\
\hline
\end{tabular}

Tabel 2. Hasil prediksi dan observasi curah hujan tahun 2016 di kota Samarinda

\begin{tabular}{llll}
\hline Bulan & Prediksi & Observasi & $\begin{array}{l}\text { Error } \\
(\%)\end{array}$ \\
\hline Januari & 138,48 & 157,8 & 12,24 \\
\hline Februari & 93,60 & 102,8 & 8,95 \\
\hline Maret & 106,05 & 117,5 & 9,74 \\
\hline April & 319,70 & 382,7 & 16,46 \\
\hline Mei & 223,44 & 243,7 & 8,31 \\
\hline Juni & 166,41 & 157,8 & 5,45 \\
\hline Juli & 174,98 & 170,8 & 2,44 \\
\hline Agustus & 122,31 & 101,1 & 20,97 \\
\hline September & 204,92 & 266,8 & 23,19 \\
\hline Oktober & 188,41 & 184,9 & 1,89 \\
\hline November & 217,36 & 292,4 & 25,66 \\
\hline Desember & 317,96 & 355,6 & 10,58 \\
\hline
\end{tabular}

Secara umum hasil prediksi curah hujan bulanan dengan menunjukkan hasil yang lebih kecil (under estimate) dari nilai aktual curah hujan bulanan tahun 2016 kecuali pada bulan Juni, Juli, Agustus dan Oktober.

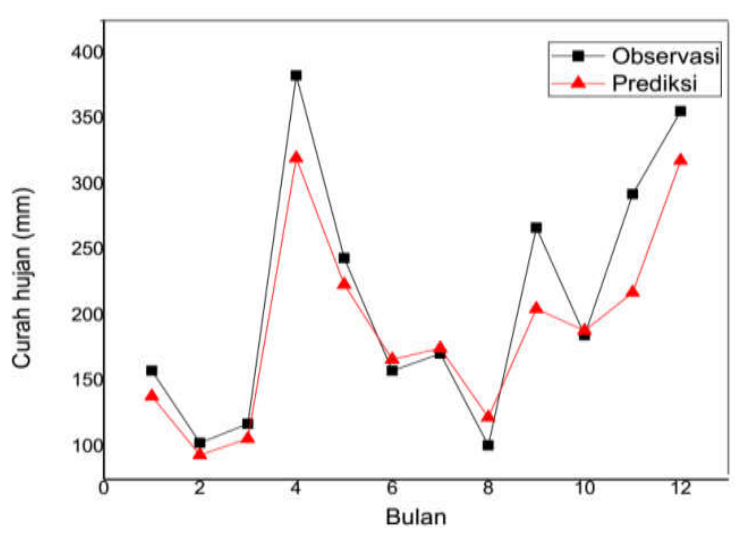

Gambar 1. Grafik Perbandingan curah hujan hasil prediksi dengan observasi tahun 2016

\section{Kesimpulan}

Prediksi curah hujan bulanan menunjuk nilai prediksi paling baik pada bulan Oktober. Nilai prediksi total hujan bulanan dengan prediktor suhu dan kelembapan udara secara umum menunjukkan hasil under estimate dari nilai obeservasinya. Prediksi curah hujan bulanan menghasilkan nilai koefisien korelasi sangat kuat dan RMSE yang baik yaitu $r=0.93$ dan RMSE $=46,26 \%$

\section{Daftar Pustaka}

Handiana, D., Wahyono, S. C., dan Susanti, D. S. (2013). Perancangan model curah hujan bulanan berdasarkan suhu permukaan air laut di Kalimantan Selatan. Jurnal Fisika Flux vol. 10 no. 1. Hal 1-12

Prawirowardoyo, S. (1996). Meteorologi Umum. Institut Teknologi Bandung. hal. 130, Bandung.

Prihatini, Djatmiko, H.T., \& Swarinoto, Y.S. (2000). Kaitan Southern Oscillation Index Dengan Total Hujan Bulanan di Pontianak. Jurnal Meteorologi \& Geologi,

Sandy, I.M. (1995). Atlas Republik Indonesia. Depok: PT Indograf Bakti \& Jurusan Geografi FMIPA-UI.

Soetamto \& Maria, U.A. (2010). Modul Pelatihan Peningkatan Akurasi Prakiraan Musim. Jakarta: BMKG.

Sudjana. (1995). Metoda Statistika. Bandung: Penerbit Tarsito.

Swarinoto, Y. (2011). Pemanfaatan suhu udara dan kelembapan udara dalam persamaan regresi untuk simulasi prediksi total hujan bulanan di Bandar Lampung. Jakarta : Jurnal Meteorologi dan Geofisika Volume 12 no. 3.

Trihendradi, C. (2005). Step By Step SPSS 13, Analisis Data Statistik. Yogyakarta: Penerbit ANDI. 
Wilks, D.S. (1995). Statistical Methods in the Atmospheric Science, San Diego: Academic Press.
Wirjohamidjojo, S. \& Swarinoto, Y.S. (2010). Iklim Kawasan Indonesia. Jakarta: Badan Meteorologi Klimatologi dan Geofisika, Jakarta. 